\title{
Effects of endogenous and exogenous secretin on plasma pancreatic polypeptide concentrations in dogs
}

\author{
F. Koizumi ${ }^{1}$, A. Ohkawa ${ }^{1}$, T. Kawamura ${ }^{1}$, A. Ishimori ${ }^{1}$, I. Sasaki ${ }^{2}$ and J. Kameyama ${ }^{2}$ \\ ${ }^{1}$ Department of Clinical and Laboratory Medicine, and \\ ${ }^{2}$ First Department of Surgery, Tohoku University School of Medicine, Sendai, Japan
}

\begin{abstract}
Summary. The effects of exogenous and endogenous secretin with or without intravenous glucose infusion upon islet hormone secretion were studied in four conscious mongrel dogs fitted with a duodenal fistula. Intravenous infusion of secretin for $1 \mathrm{~h}$ at doses of 0.5 and $4 \mathrm{U} / \mathrm{kg}$ raised plasma secretin concentrations to physiological and pharmacological levels respectively, without affecting plasma insulin and pancreatic polypeptide concentrations. In contrast, bolus injections of secretin at high concentrations produced significant increases of plasma insulin at $0.5 \mathrm{U} / \mathrm{kg}$ and $4 \mathrm{U} / \mathrm{kg}$ and of pancreatic polypeptide at $4 \mathrm{U} / \mathrm{kg}$. Plasma glucagon did not change during intravenous infusion of low dose secretin $\left(0.5 \mathrm{U} \cdot \mathrm{kg}^{-1}\right.$. $\left.\mathrm{h}^{-1}\right)$, but decreased during infusion of $4 \mathrm{U} \cdot \mathrm{kg}^{-1} \cdot \mathrm{h}^{-1}$ or bolus injection of secretin $(0.5 \mathrm{U} / \mathrm{kg})$. Intravenous infusion of glucose together with secretin $(0.5 \mathrm{U} / \mathrm{kg}$ and $4 \mathrm{U} / \mathrm{kg})$ did not af-
\end{abstract}

fect plasma insulin, glucagon, or pancreatic polypeptide levels significantly compared with the changes caused by glucose infusion alone. Intraduodenal instillation of $\mathrm{HCl}$, which produced plasma secretin concentrations similar to those evoked by intravenous infusion of secretin $\left(4 \mathrm{U} \cdot \mathrm{kg}^{-1} \cdot \mathrm{h}^{-1}\right)$, led to a rise in plasma pancreatic polypeptide. It is concluded that the stimulatory effects of secretin on insulin and pancreatic polypeptide and the inhibitory effect on glucagon are pharmacological, and that increase of plasma pancreatic polypeptide after intraduodenal infusion of $\mathrm{HCl}$ is not mediated by endogenous secretin.

Key words: Secretin, insulin, glucagon, pancreatic polypeptide, intravenous glucose, intraduodenal acid.

secretin with or without glucose infusion affect insulin, glucagon and PP secretion. In addition, the effect of intraduodenal hydrochloric acid instillation, a stimulus of endogenous secretin [16], on pancreatic hormone responses was studied.

\section{Materials and methods}

Four healthy mongrel dogs (weight $15-31 \mathrm{~kg}$ ) were studied during the conscious state. In order to infuse $\mathrm{HCl}$ intraduodenally, each dog was fitted with a duodenal fistula by insertion of a Gregory cannula into the proximal half of the first part of the duodenum. Animals were fasted for $18 \mathrm{~h}$ prior to study, but had free access to water. The dogs received, in random order on separate days at intervals of not less than 3 weeks, 1 of the following 10 regimens: (1) a 60-min intravenous infusion of glucose at a rate of $0.5 \mathrm{~g} \cdot \mathrm{kg}^{-1} \cdot \mathrm{h}^{-1}$; (2) a 60 -min intravenous infusion of secretin at a rate of $0.5 \mathrm{U} \cdot \mathrm{kg}^{-1} \cdot \mathrm{h}^{-1} ;$, (3) regimen (1) + regimen (2); (4) a 60-min intravenous infusion of secretin at a rate of $4 \mathrm{U} \cdot \mathrm{kg}^{-1} \cdot \mathrm{h}^{-1}$; (5) regimen (1) + regimen (4); (6) a rapid intravenous bolus of secretin at a rate of $0.5 \mathrm{U} / \mathrm{kg} ;(7)$ a rapid intravenous bolus of secretin at a rate of $4 \mathrm{U} / \mathrm{kg}$; (8) a 30-min intravenous infusion of glucose at a rate of $1 \mathrm{~g} \cdot \mathrm{kg}^{-1} \cdot \mathrm{h}^{-1} ;(9)$ a 30 -min intraduodenal infusion of $250 \mathrm{mmol} / 1 \mathrm{HCl}$ at a rate of $200 \mathrm{ml} / \mathrm{h} ;(10)$ regimen (8) + regimen (9). In each dog, two investigations were carried out. Natural secretin (Secrepan), a pure extract of porcine duodenum and jejunum not containing any active glucagon, vasoactive intestinal peptide, cholecysto-
The present study was designed to explore whether

physiological and pharmacological doses of exogenous cation also stimulates PP release in man [8] and dogs [15], there are no comparable studies which show whether PP release by intraduodenal acidification is mediated by endogenous secretin. 


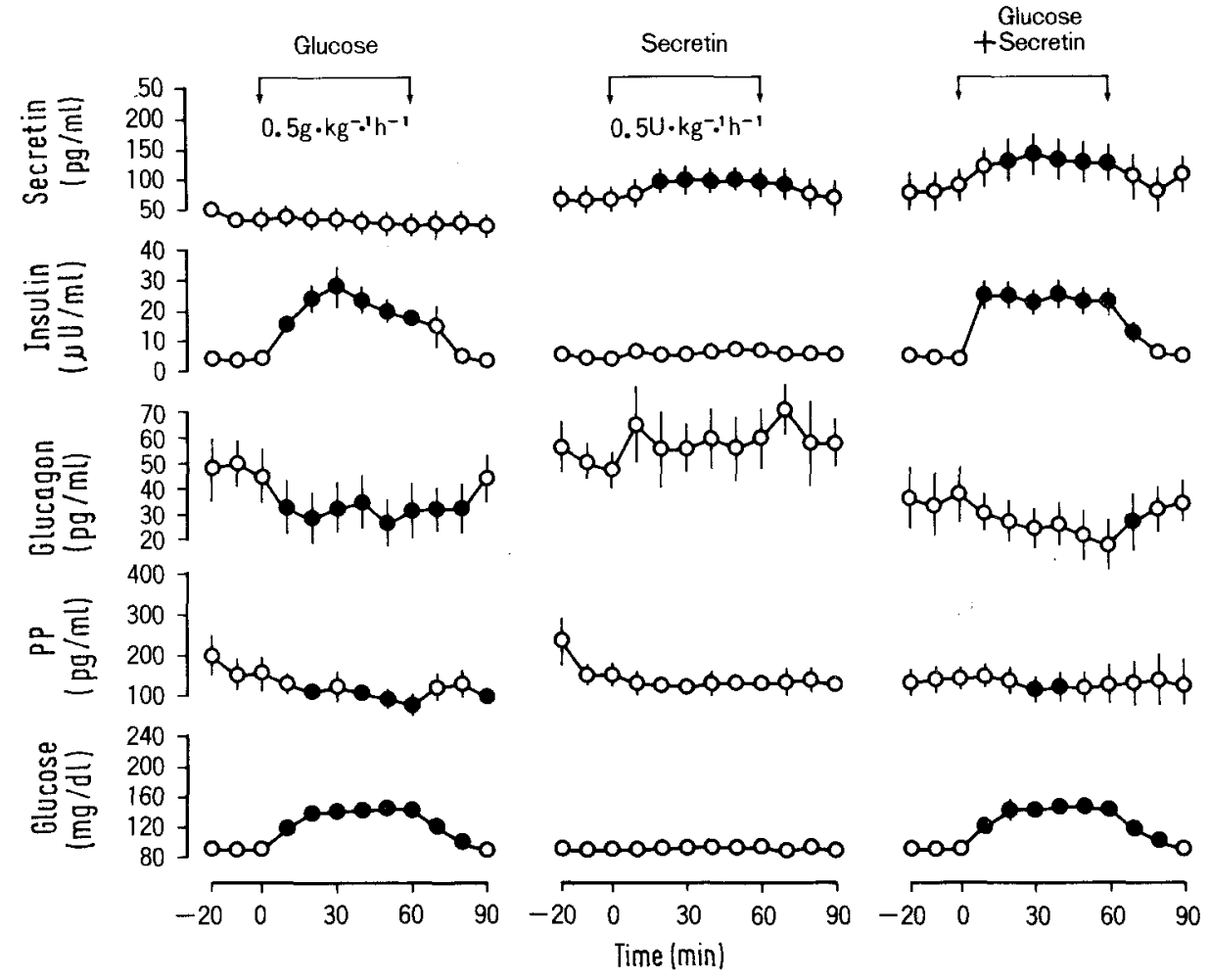

Fig. 1. Effects of intravenous infusions of glucose $\left(0.5 \mathrm{~g} \cdot \mathrm{kg}^{-1} \cdot \mathrm{h}^{-1}\right)$, secretin $\left(0.5 \mathrm{U} \cdot \mathrm{kg}^{-1} \cdot \mathrm{h}^{-1}\right)$, and glucose with secretin on plasma secretin, insulin, glucagon, PP and glucose concentrations. The results of eight individual experiments are shown. Closed circles indicate significant differences from baseline levels kinin or PP, was obtained from the Eisai Co. (Tokyo, Japan). The Eisai unit was compared directly with the clinical unit (GIH unit) by bioassay in rats, the potency of the latter being about 4 times greater than that of the former [17]. Secretin was dissolved in isotonic saline immediately before use. Secretin or glucose was infused into the foreleg vein using a syringe ram pump via an indwelling intravenous catheter.

Blood samples were obtained at frequent intervals before, during, and after stimulations using a second catheter placed in the foreleg vein of the opposite side. Samples for radioimmunoassay of secretin, insulin, glucagon and PP were collected in heparinized tubes with the addition of aprotinin $(250 \mathrm{KIU} / \mathrm{ml}$ blood); they were kept chilled in an ice bath until centrifugation at $4{ }^{\circ} \mathrm{C}$, and the plasma were stored frozen at $-80^{\circ} \mathrm{C}$ until assayed. For the determination of plasma glucose, small samples of blood were collected into heparinized tubes containing a glycolysis inhibitor (sodium iodoacetate).

Plasma secretin [9], glucagon [18] and PP [9] were measured by radioimmunoassay as described recently. The plasma insulin concentration was determined using polyethylene glycol precipitation and a double antibody method employing a commercially available kit system (Midori-Juji, Osaka, Japan). Plasma glucose levels were measured by the glucose-oxidase method using an automated glucose analyzer (Glucoroder-S, Analytical Instrument, Tokyo, Japan).

\section{Statistical analysis}

Basal values represent the mean of three consecutive samples taken before stimulation. Data are presented as the mean \pm SEM. For statistical analysis, the Student's t-test for small paired and non-paired data was employed, and $p$ values $\leqslant 0.05$ were considered to be significant.

\section{Results}

Intravenous infusions of glucose and secretin at physiological levels.

Infusion of glucose at a dose of $0.5 \mathrm{~g} / \mathrm{kg}$ for $60 \mathrm{~min}$ caused expected rises in plasma glucose $(p<$
$0.05-0.001)$ and insulin $(p<0.001)$, but decreases in plasma glucagon $(p<0.02-0.001)$ and PP $(p<$ $0.05-0.01)$. No significant change was observed in the plasma secretin concentration (Figs. 1, 2).

After infusion of secretion at a dose of $0.5 \mathrm{U} / \mathrm{kg}$, the plasma secretin level rose from a baseline value of $71 \pm 29 \mathrm{pg} / \mathrm{ml}$ to $99 \pm 18 \mathrm{pg} / \mathrm{ml}$ at $50 \mathrm{~min}(p<0.01)$. No significant changes occurred in plasma levels of pancreatic hormones or glucose (Fig. 1).

Infusion of secretin at a dose of $0.5 \mathrm{U} / \mathrm{kg}$ together with glucose infusion was associated with increases in plasma secretin, glucose and insulin, and with decreases in plasma glucagon and PP. These changes were not significantly different from the changes caused by glucose infusion alone (Fig. 1).

\section{Intravenous infusions of glucose and secretin at pharmacological levels}

After infusion of secretin at a dose of $4 \mathrm{U} / \mathrm{kg}$, the plasma secretin level rose from the baseline $72 \pm 28 \mathrm{pg} / \mathrm{ml}$ to $257 \pm 28 \mathrm{pg} / \mathrm{ml}$ at $40 \mathrm{~min}(p<0.001)$. The plasma glucagon level decreased by $24 \pm 7 \mathrm{pg} / \mathrm{ml}$ at $60 \mathrm{~min}(p<$ 0.05 ), but no significant changes occurred in plasma PP, insulin or glucose levels (Fig. 2).

Infusion of secretin at a dose of $4 \mathrm{U} / \mathrm{kg}$ together with glucose infusion was associated with rises in plasma secretin, glucose and insulin, and with decreases in plasma glucagon and PP. These changes were not significantly different from those observed after infusion of glucose alone (Fig. 2). 

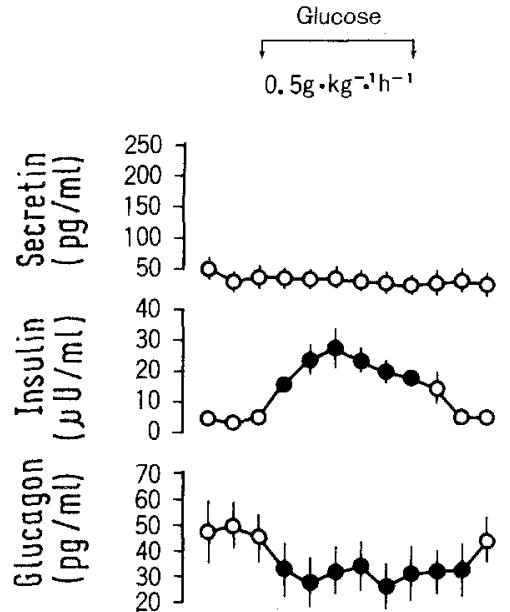

a $\frac{\overline{\vec{E}}}{\underline{B}}$

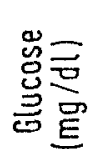

号三
总品
400
300
200
100
240
200
160
120
80

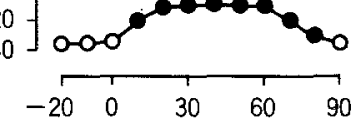

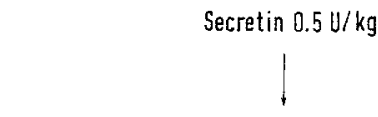
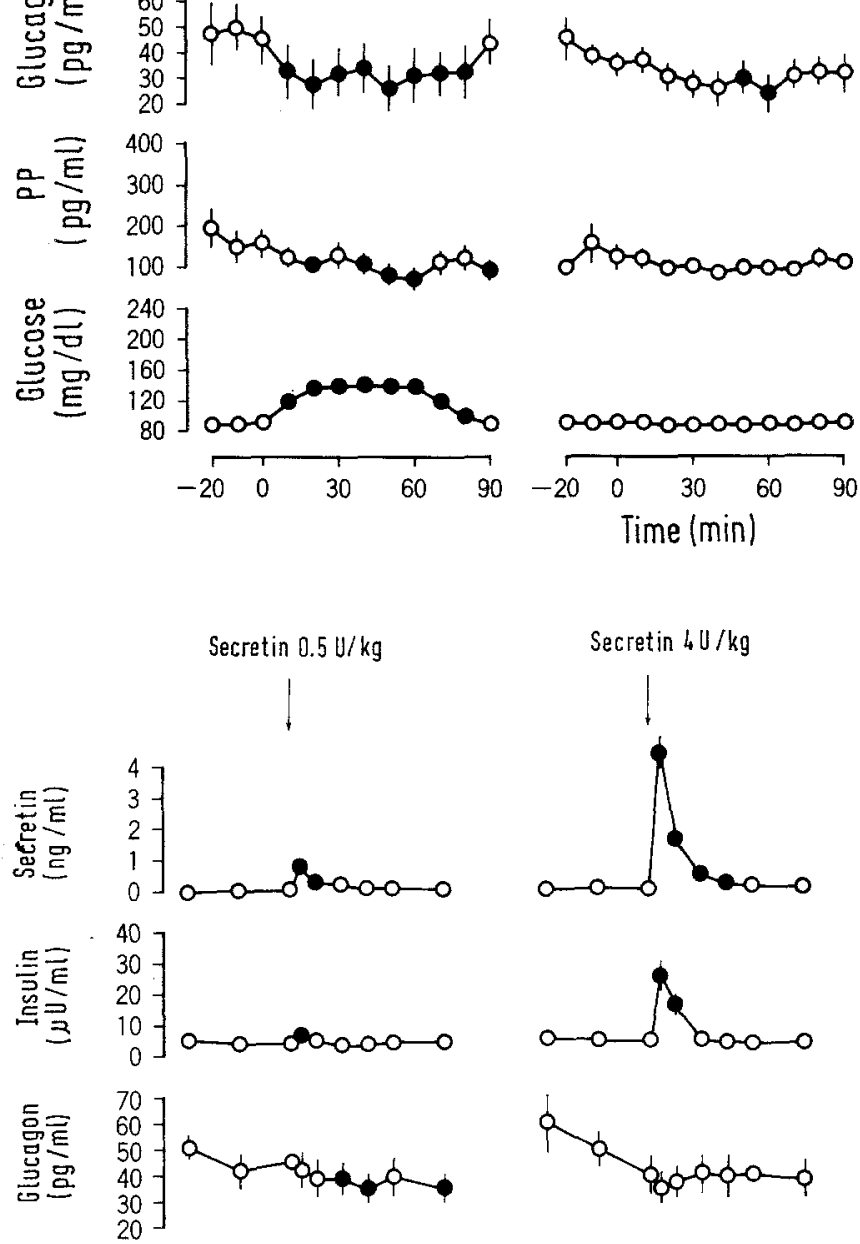

Time (min)

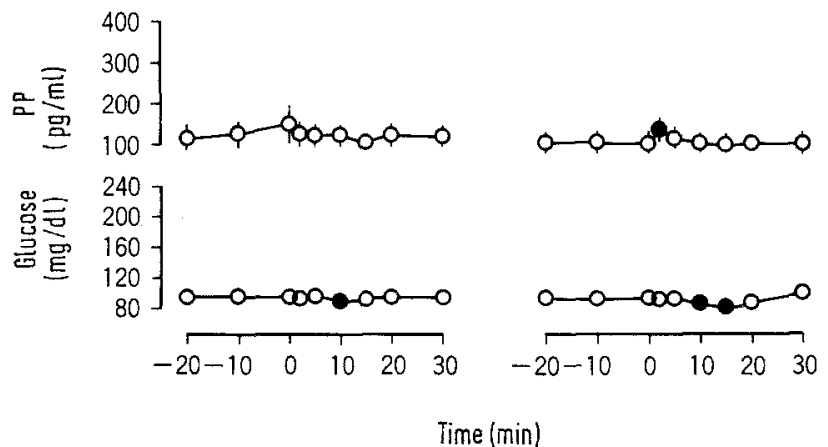

Fig.3. Effects of rapid intravenous injections of secretin $(0.5 \mathrm{U} / \mathrm{kg}$ and $4 \mathrm{U} / \mathrm{kg}$ ) on the plasma secretin, insulin, glucagon, PP and glucose concentrations. The results of eight individual experiments are shown. Closed circles indicate significant differences from baseline levels
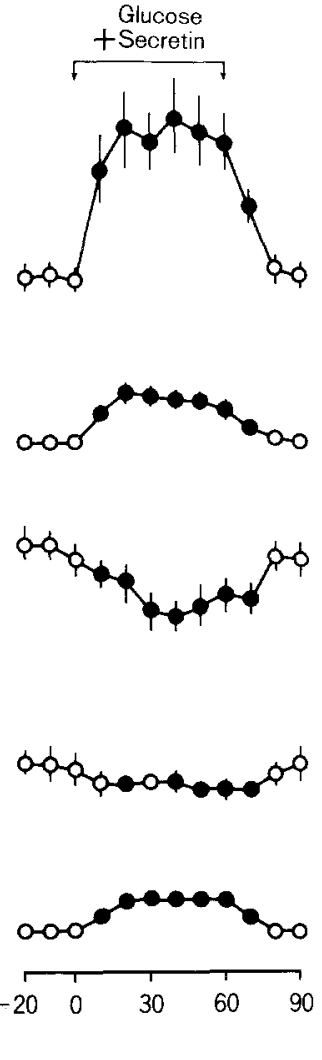

Fig. 2. Effects of intravenous infusions of glucose $\left(0.5 \mathrm{~g} \cdot \mathrm{kg}^{-1} \cdot \mathrm{h}^{-1}\right)$, secretin $(4 \mathrm{U}$. $\left.\mathrm{kg}^{-1} \cdot \mathrm{h}^{-1}\right)$, and glucose with secretin on plasma secretin, insulin, glucagon, $\mathrm{PP}$ and glucose concentrations. The results of eight individual experiments are shown. Closed circles indicate significant differences from baseline levels

\section{Effects of rapid intravenous injections of secretin}

After a secretin pulse $(0.5 \mathrm{U} / \mathrm{kg})$ was administered, the plasma secretin concentration rose from $31 \pm 22 \mathrm{pg} / \mathrm{ml}$ to a peak value of $873 \pm 87 \mathrm{pg} / \mathrm{ml}$ at $2 \mathrm{~min}(p<0.001)$. A small but significant rise was observed in the plasma insulin concentration $(p<0.05)$, together with significant decreases in plasma glucagon $(p<0.05, p<0.01)$ and glucose $(p<0.02)$ concentrations. The plasma PP concentration did not significantly change (Fig.3).

The rapid injection of secretin $(4 \mathrm{U} / \mathrm{kg})$ resulted in a striking rise in the plasma secretin concentration from $36 \pm 24 \mathrm{pg} / \mathrm{ml}$ to a peak value of $4296 \pm 367 \mathrm{pg} / \mathrm{ml}$ at 2 min $(p<0.001)$. In addition, a highly significant increase in the plasma insulin concentration to a peak of $27 \pm 4 \mu \mathrm{U} / \mathrm{ml}$ was observed at $2 \mathrm{~min}(p<0.01)$. The plasma glucose level started to fall within $10 \mathrm{~min}$, although it remained constant during the first $5 \mathrm{~min}$. A small, insignificant decrease in plasma glucagon, and a significant $(p<0.02)$ but transient increase in plasma PP from $108 \pm 24 \mathrm{pg} / \mathrm{ml}$ to the maximum level of $133 \pm$ $27 \mathrm{pg} / \mathrm{ml}$ at $2 \mathrm{~min}$, were observed (Fig. 3).

\section{Intravenous infusions of glucose and/or intraduodenal infusion of $\mathrm{HCl}$}

After infusion of glucose $\left(1.0 \mathrm{~g} \cdot \mathrm{kg}^{-1} \cdot \mathrm{h}^{-1}\right)$ for $30 \mathrm{~min}$, plasma insulin rose in parallel with a rise of plasma glucose. Basal plasma glucagon and PP declined progressively. No significant change of the plasma secretin concentration was measured (Fig. 4). 


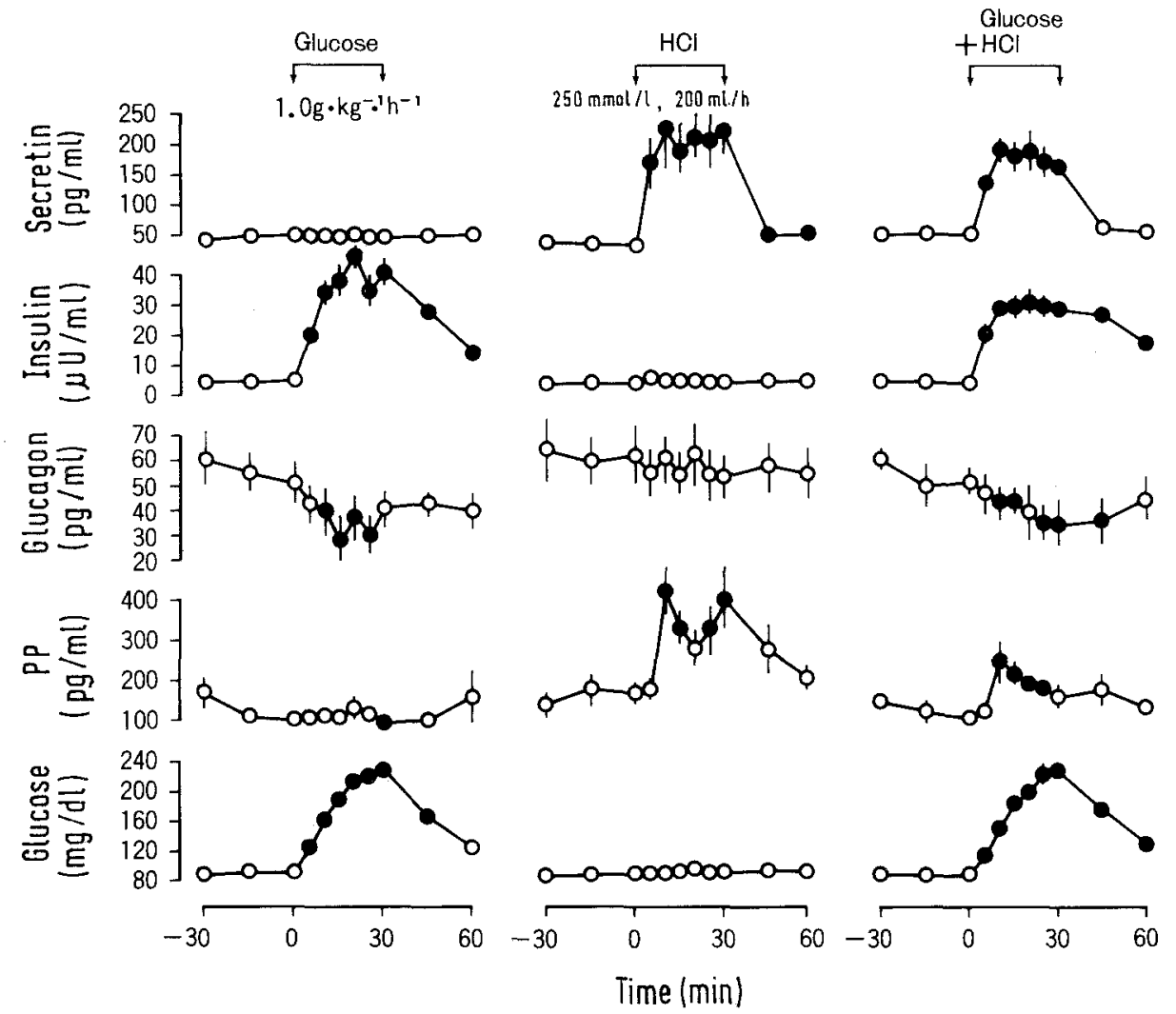

Fig.4. Effects of intravenous infusion of glucose $\left(1.0 \mathrm{~g} \cdot \mathrm{kg}^{-1} \cdot \mathrm{h}^{-1}\right)$, intraduodenal infusion of $\mathrm{HCl}(250 \mathrm{mmol} / 1,200 \mathrm{ml} / \mathrm{h})$, and intravenous infusion of glucose together with intraduodenal infusion of $\mathrm{HCl}$ on plasma secretin, insulin, glucagon, $\mathrm{PP}$ and glucose concentrations. The results of eight individual experiments are shown. Closed circles indicate significant differences from baseline levels
The infusion of $\mathrm{HCl}(250 \mathrm{mmol} / 1,100 \mathrm{ml})$ into the duodenum over $30 \mathrm{~min}$ resulted in a significant rise in the plasma secretin concentration $(p<0.05-0.01)$, reaching a peak value of $225 \pm 63 \mathrm{pg} / \mathrm{ml}$ at $10 \mathrm{~min}$; this was also the case for intravenous infusion of $4 \mathrm{U} / \mathrm{kg}$ secretin. Plasma PP also increased, somewhat later than the plasma secretin increase, from $165 \pm 28 \mathrm{pg} / \mathrm{ml}$ to a peak of $424 \pm 56 \mathrm{pg} / \mathrm{ml}(p<0.01)$, showing a biphasic pattern. Plasma insulin, glucagon and glucose concentrations were unaffected (Fig. 4). In two dogs, no change of plasma hormones or glucose levels during intraduodenal infusions of $100 \mathrm{ml}$ saline was seen (data not shown).

Intraduodenal infusion of $\mathrm{HCl}$ during intravenous infusion of glucose produced an increase in plasma secretin, insulin, PP and glucose, and a decrease in plasma glucagon. However, the insulin responses during 20 $(32 \pm 4 \mu \mathrm{U} / \mathrm{ml})$ and $30(29 \pm 3 \mu \mathrm{U} / \mathrm{ml})$ min periods were significantly smaller than those after glucose infusion alone $(p<0.02)$. The corresponding PP increases were significantly smaller than after $\mathrm{HCl}$ infusion alone $(p<$ $0.05, p<0.01$ ). Regarding plasma glucagon and glucose, the changes following the glucose $+\mathrm{HCl}$ administration were similar to those following glucose infusion alone (Fig.4).

\section{Discussion}

In the present study, intravenous infusion or bolus injection of two different doses of $0.5 \mathrm{U} / \mathrm{kg}$ and $4 \mathrm{U} / \mathrm{kg}$ secretin was used. Only the $0.5 \mathrm{U} / \mathrm{kg}$ dose of secretin for $1 \mathrm{~h}$ raised plasma secretin to a magnitude similar to that found after a meal in dogs [9]. Therefore, this dose is considered to be within the physiological range.

Previous studies have demonstrated two major effects of secretin on insulin secretion: a direct effect in the form of a rapid transient monophasic insulin response $[14,19-26]$ and an indirect effect by which secretin promotes increased islet responsiveness to other stimuli [10, 21, 24-29]. However, others have reported no effect [30-32]. In our present study, infusion of secretin in a dose of $0.5 \mathrm{U} \cdot \mathrm{kg}^{-1} \cdot \mathrm{h}^{-1}$ and $4 \mathrm{U} \cdot \mathrm{kg}^{-1} \cdot \mathrm{h}^{-1}$ with or without glucose had no direct or synergistic stimulatory effect on insulin response. Only after bolus injection of secretin, which brought about a rapid increase in the plasma secretin concentration to pharmacological levels, was a direct stimulatory effect of secretin observed. These results indicate that dose level of secretin is the major factor affecting insulin release, and that the physiological importance of secretin is doubted.

Several laboratories have obtained contradictory results for glucagon release when exogenous secretin was administered in vivo and in vitro [10, 20, 22-24, 29, 32]. No significant change was observed during the infusion of secretin in a physiological dose of $0.5 \mathrm{U} \cdot \mathrm{kg}^{-1} \cdot \mathrm{h}^{-1}$. In addition, no significant alteration of circulating glucagon levels could be demonstrated with 0.5 or $4 \mathrm{U} / \mathrm{kg}$ secretin during glucose infusion. There was a significant fall in glucagon levels during secretin infusion of $4 \mathrm{U} /$ $\mathrm{kg}$ and after a secretin bolus injection of $0.5 \mathrm{U} / \mathrm{kg}$. 
These doses, however, resulted in increased plasma secretin levels which were far above the upper limit of physiological range $(125 \mathrm{pg} / \mathrm{ml})$, as revealed from our previous study [9]. Therefore, the physiological importance of secretin on glucagon release is questionable.

There are several reports dealing with the effect of secretin on PP secretion from the pancreas in man $[5,6$, $11,12,14]$ and in experimental animals $[10,13]$; some authors have reported stimulation of PP $[5,6,12]$, while others failed to observe any effects $[6,10,11,13,14]$. In the present study, the infusion of secretin either at 0.5 or $4 \mathrm{U} \cdot \mathrm{kg}^{-1} \cdot \mathrm{h}^{-1}$ was ineffective on basal and glucose-inhibited PP secretion, and only after a secretin bolus $(4 \mathrm{U} / \mathrm{kg})$ did a small but significant release of PP occur. These results indicate that plasma PP release is dependent on the rapidity of secretin administration, and that secretin does not play a role in PP release under physiological conditions. The small plasma PP response after a secretin bolus injection is at variance with observations in other studies in humans $[5,6,12]$. This difference may be explained in part by species differences.

Intestinal acidification is presently recognized as a stimulus for secretin release into the blood [16]. In our present study, $\mathrm{HCl}$ instillation resulted in plasma secretin release, comparable to the increment seen during intravenous infusion of secretin at a dose of $4 \mathrm{U} \cdot \mathrm{kg}^{-1}$. $\mathrm{h}^{-1}$. Plasma PP also increased after intraduodenal acidification, whereas plasma PP did not increase during secretin infusion of $4 \mathrm{U} \cdot \mathrm{kg}^{-1} \cdot \mathrm{h}^{-1}$. Therefore, it seems unlikely that endogenous secretin release caused the observed $\mathrm{PP}$ response after intraduodenal $\mathrm{HCl}$ infusion. The mean postprandial PP response during histamine $\mathrm{H}_{2}$-receptor blockade did not differ significantly from that seen without histamine $\mathrm{H}_{2}$-receptor blockade in man [8] and in dogs [9]. Therefore, the importance of the intraduodenal $\mathrm{pH}$ as the cause of $\mathrm{HCl}$-stimulated $P P$ release is doubted. The distending effect of the infused volume can be neglected, since duodenal distension with saline had no effect on PP release. Gastrointestinal peptides such as cholecystokinin (CCK) [33] and vasoactive intestinal peptide (VIP) [34], which were not measured but are also released during duodenal acidification, may be a partial mediator in the overall response of plasma PP to duodenal acidification.

Intravenous glucose infusions depressed the PP response to the ingestion of a protein rich meal as well as to intravenous infusion of caerulein [35]. In our study, PP response induced by intraduodenal instillation of $\mathrm{HCl}$ was significantly inhibited during intravenous glucose infusion. Insulin response induced by intravenous infusion of glucose also was significantly inhibited by intraduodenal infusion of $\mathrm{HCl}$. These findings suggest the possibility of interaction between glucose, PP and insulin secretion. Further studies are needed to explore the existence of such an interaction in the normal postprandial state.

This study has shown that stimulation of plasma insulin and PP as well as depression of plasma glucagon were observed only when the plasma secretin concentration was at pharmacological levels. There is no evidence that secretin plays a significant role in the enteroinsular and entero-PP axis under normal physiological conditions.

\section{References}

1. Kimmel JR, Pollock HG, Hazelwood RL (1968) Isolation and characterization of chicken insulin. Endocrinology 83: 1323-1330

2. Lin TM, Chance RE (1974) Bovine pancreatic polypeptide (BPP) and avian pancreatic polypeptide (APP). Gastroenterology 67: 737-738

3. Adrian TE, Bloom SR, Bryant MG, PolakJM, Heitz PH, Bames AJ (1976) Distribution and release of human pancreatic polypeptide. Gut 17:940-944

4. Schwartz TW, Rehfeld JF, Stadil F, Larson LI, Chance RE, Moon N (1976) Pancreatic-polypeptide response to food in duodenal-ulcer patients before and after vagotomy. Lancet 1: 1102-1105

5. Adrian TE, Bloom SR, Besterman HS, Barnes AJ, Cooke TJC, Russell RCG, Faber RG (1977) Mechanism of pancreatic polypeptide release in man. Lancet 1: 161-163

6. Adrian TE, Bloom SR, Besterman HS, Bryant MG (1978) PP physiology and pathology. In: Bloom SR (ed) Gut hormones, Churchill Livingstone, Edinburgh, pp 254-260

7. Taylor IL, Impicciatore M, Carter DC, Walsh JH (1978) Effect of atropine and vagotomy on pancreatic polypeptide response to a meal in dogs. Am J Physiol 235: E443-E447

8. Jorde R, Burhol PG (1982) Duodenal acid is without importance for the postprandial PP release. Scand J Gastroenterol 17: 681-685

9. Koizumi F, Ushizawa R, Kawamura T, Ishimori A, Sasaki I, Kameyama J (1984) Effect of meal and cimetidine on endogenous plasma gastrin, secretin and pancreatic polypeptide in experimental acid hypersecretion in dogs. Tohoku J Exp Med 143: 17-25

10. Adrian TE, Bloom SR, Hermansen K, Iversen J (1978) Pancreatic polypeptide, glucagon and insulin secretion from the isolated perfused canine pancreas. Diabetologia 14: 413-417

11. Adrian TE, Besterman HS, Mallinson $C N$, Greenberg GR, Bloom SR (1978) Inhibition of secretin stimulated pancreatic secretion by pancreatic polypeptide. Gut $20: 37-40$

12. Glaser B, Vinik AI, Sive AA, Floyd JCJr (1980) Plasma human pancreatic polypeptide responses to administered secretin: Effects of surgical vagotomy, cholinergic blockade, and chronic pancreatitis. J Clin Endocrinol Metab 50: 1094-1099

13. Guzman S, Lonovics J, Devitt PG, Hejtmancik KE, Rayford PL, Thompson JC (1981) Hormone-stimulated release of pancreatic polypeptide before and after vagotomy in dogs. Am J Physiol 240: G114-G121

14. Florholmen J, Burhol PG, Jorde R, Waldum HL (1984) The effect of graded doses of secretin on serum trypsin, serum pancreatic amylase, serum insulin, plasma somatostatin, and plasma pancreatic polypeptide in man. Scand J Gastroenterol 19:24-30

15. Kayasseh L, Haecki WH, Gyr K, Stalder GA, Rittmann WW, Halter F, Girard J (1978) The endogenous release of pancreatic polypeptide by acid and meal in dogs. Scand $J$ Gastroenterol 13: 385-391

16. Koizumi F, Ishimori A, Koizumi M (1980) Measurement of secretin in the mucosa of digestive tract by radioimmunoassay. Tohoku J Exp Med 131: 339-346

17. Tachibana S (1971) The bioassay of secretin in the rat. Jpn J Pharmacol 21: $325-336$

18. Koizumi F, Kawamura T, Ishimori A, Sasaki I, Kameyama J (1985) Gastric acid secretion, intraduodenal $\mathrm{pH}$ and gastroenteropancreatic hormone release to bombesin in antrocolic transposition dogs. Tohoku J Exp Med 145: 65-72 
19. Boyns DR, Jarrett RJ, Keen $H$ (1967) Intestinal hormones and plasma insulin: an insulinotropic action of secretin. Br Med J 2: 676-678

20. Unger RH, Ketterer H, Dupré J, Eisentraut AM (1967) The effects of secretin, pancreozymin, and gastrin on insulin and glucagon secretion in anesthetized dogs. J Clin Invest 46: 630-645

21. Lerner RL, Porte DJr (1972) Studies of secretin-stimulated insulin responses in man. J Clin Invest 51: 2205-2210

22. Ohneda A, Sato M, Matsuda K, Yanbe A, Maruhama Y, Yamagata S (1972) Plasma glucagon response to blood glucose fall, gastrointestinal hormones and arginine in man. Tohoku J Exp Med 107: 241-251

23. Santeusanio F, Faloona GR, Unger RH (1972) Suppressive effect of secretin upon pancreatic alpha cell function. J Clin Invest 51: 1743-1749

24. Dud1 RJ, Lerner RL, Ensinck JW, Williams RH (1973) The effect of secretin on pancreatic glucoregulatory hormones in man. Horm Metab Res 5:250-253

25. Lerner RL (1976) The augmentation effect of secretin on the insulin responses to known stimuli: specificity for glucose. J Clin Endocrinol Metab 45: 1-9

26. Ahrén B, Lundquist I (1981) Effects of vasoactive intestinal polypeptide (VIP), secretin and gastrin on insulin secretion in the mouse. Diabetologia 20:54-59

27. Dupre J, Curtis JD, Unger RH, Waddell RW, Beck JC (1969) Effects of secretin, pancreozymin, or gastrin on the response of the endocrine pancreas to administration of glucose or arginine in man. J Clin Invest 48: 745-757

28. Fahrenkrug J, Schaffalitzky de Muckadell OB, Kühl C (1978) Effect of secretin on basal- and glucose-stimulated insulin secretion in man. Diabetologia 14: 229-234
29. Hisatomi A, Unger RH (1983) Secretin inhibits glucagon in the isolated perfused dog pancreas. Diabetes 32: 970-973

30. Schaffalitzky de Muckadell OB, Fahrenkrug J, Kühl C (1976) Plasma insulin concentration during physiological variations in immunoreactive plasma secretin. Horm Metab Res 8: 253-256

31. Brodows RG, Chey WY (1980) Physiological doses of secretin do not stimulate acute insulin release. J Clin Endocrinol Metab 50: 603-606

32. Otsuki M, Sakamoto C, Ohki A, Yuu H, Morita S, Baba S (1981) Effects of porcine secretin on exocrine and endocrine function in the isolated perfused rat pancreas. Am J Physiol 241: G43-G48

33. Reeder DD, Becker HD, Smith NJ, Rayford PL, Thompson JC (1973) Measurement of endogenous release of cholecystokinin by radioimmunoassay. Ann Surg 178: 304-310

34. Schaffalitzky de Muckadell OB, Fahrenkrug J, Holst JJ, Lauritsen KB (1977) Release of vasoactive intestinal polypeptide (VIP) by intraduodenal stimuli. Scand J Gastroenterol 12: 793-799

35. Marco J, Hedo JA, Castillo-Olivares J, Villanueva ML (1980) Human pancreatic polypeptide secretion in conditions of exogenous and endogenous hyperglycaemia. Diabetologia 19: 418- 422

Received: 27 February 1985

and in revised form: 31 December 1985

\section{Dr. F. Koizumi}

Department of Clinical and Laboratory Medicine

Tohoku University School of Medicine

Seiryocho 1-1, Sendai

Japan 